\title{
A Policy Mapping Analysis of Goals Related to Bank Accounts in Federal Legislative Proposals
}

\author{
Julie Birkenmaier $^{1}$ D Alana Janssen ${ }^{2}$
}

Accepted: 22 July 2021 / Published online: 21 August 2021

(c) The Author(s), under exclusive licence to Springer Nature Switzerland AG 2021

\begin{abstract}
The US struggles to fully bank the unbanked and underbanked populations. This paper examined the policy landscape around these efforts by exploring the following research questions: (1) What policy goals that may impact the availability of low-cost, basic bank accounts that have been introduced in Congress as legislation? (2) How far in the legislative process did the legislation advance? (3) What populations did these proposed laws target? and (4) What related policy goals were pursued most ardently over the past 20 years? We conducted a policy mapping content analysis of all bank account-related bills $(N=32)$ proposed in Congress between 1999 and 2020 (May) (106th-116th Congresses). Two researchers independently coded basic characteristics (e.g., type, status, sponsorship), focal populations, and illustrative mechanisms for policy goals using a taxonomy developed by the researchers. Researchers compared codes and addressed discrepancies through consensus. New codes were created as needed. Goals appearing most often were expanding access to bank accounts (81.2\%), increasing consumer protection $(81.2 \%)$, and reducing costs of basic accounts (78.2\%). Increasing consumer disclosure (37.5\%) and expanding the type of institutions that offer basic accounts $(9.4 \%)$ were addressed infrequently in the legislation. No legislation addressed the policy goal of expanding account access in minority populations and communities. Explicit attention toward unbanked and underbanked households, racial/ethnic minorities, and other vulnerable populations was rare. This study represents the first systematic analysis of key features of the US congressional response to the problem of affordability and accessibility of bank accounts. Legislative attention to the policy goals of expanding access and types of institutions that offer accounts is needed.
\end{abstract}

Keywords Policy mapping $\cdot$ Legislation $\cdot$ Bank accounts $\cdot$ Congress

Julie Birkenmaier

Julie.Birkenmaier@slu.edu

Alana Janssen

alana@lovethelou.com

1 College for Public Health and Social Justice, Saint Louis University School of Social Work, 3550 Lindell Blvd, St. Louis, MO 63103, USA

2 LOVEtheLOU, St. Louis, MO, USA 


\section{Introduction}

Recent efforts by national prominent organizations have added momentum to ongoing campaigns by various groups to encourage consumers to own a bank account and for banks to offer affordable, safe bank accounts (CFE, 2020). For example, during the COVID-19 pandemic, the Federal Deposit Insurance Corporation (FDIC) is hosting a "get banked" campaign to persuade consumers to open a bank account so they can easily and quickly receive federal stimulus payments (FDIC, 2021). At the same time, the American Bankers Association is encouraging all banks to offer lowcost, basic accounts that meet national standards for functionality and affordability (ABA, 2021).

This recent attention in practice mirrors increased attention in policy arenas and by researchers. For several decades, scholars and government entities (e.g., the FDIC, the Federal Reserve, and Congressional committees) have called attention to the problem of unbanked and underbanked in the USA (Barabaran, 2020; Board of Governors of the Federal Reserve, 2019; FDIC, 2009, 2012a, 2014, 2016b, 2018, 2020). In 2019, an estimated $5.4 \%$ of US households had no bank account (are "unbanked") (FDIC, 2020). Unbanked individuals live in a household where no one has a checking or savings account at a bank or credit union (FDIC, 2020). These individuals take care of their banking needs through the use of cash, and/ or use of alternative financial services (AFSs), such as general purpose reloadable prepaid debit cards, check cashiers, non-bank money orders, and auto title loans. Another $18.7 \%$ have an account but also used AFS (are "underbanked") (FDIC, 2018). Underbanked individuals use the same types of AFS as unbanked individuals for purposes of convenience, preference, avoidance of fees, and other reasons (FDIC, 2018). Unbanked and underbanked rates are higher among lower-income, less-educated, Black, Hispanic, American Indian, or Alaska Native, working-age disabled households, and households with volatile income (FDIC, 2020).

Lacking a bank account at a financial institution, or not fully using an account or the banked relationship for other products and services, can be problematic in several ways. First, without an account, consumers spend an average of $9.5 \%$ of their annual income on fees (Office of the Inspector General, United States Postal Service, 2014). Second, the unbanked and underbanked also suffer the cost and indignities of financial exclusion, a lack of "financial citizenship" that creates a bifurcated culture of those within and those outside of mainstream financial institutions, and must pay more for credit than those fully within mainstream financial institutions (Servon \& Castro-Cosio, 2015).

The challenges of the unbanked and underbanked have structural roots in policy related to the financial system. Mainstream financial institutions, (i.e., retail banks and credit unions) provide basic bank accounts for the majority of the US population, yet policy falls short of sufficiently incentivizing or requiring them to provide basic accounts for everyone. Policy solutions have long been proposed by scholars and policymakers to reduce or eliminate financial exclusion related to accounts. Yet little research has systematically analyzed Congressional proposals to 
these problems. This paper examines them and their fate. Results will inform future related policy efforts to reduce these populations.

\section{Background}

\section{Unbanked and Underbanked as a Policy Problem}

While the remedies for the unbanked and underbanked problem appear, at face value, to lie at the consumer level, several important aspects of these challenges are rooted in policy. These aspects include the type of institution offering accounts, the ability or willingness to optimize incentives to create needed account products, and physical access challenges.

\section{Type of Institution}

The type of institutions that offers an account, and its incentives and rewards, may play a role. In the USA, only government-chartered financial institutions offer bank accounts with consumer protections (American Banker, 2014). The products and services offered by banks and credit unions are influenced by their competitive marketplace, their mandate to produce a profit, and by government regulations. Within this environment, offering affordable basic accounts for the unbanked and underbanked is often not profitable nor attractive (Geffner, 2010). Less than half of banks create products and services for underserved consumers (FDIC, 2012b). Banks often charge fees to pay for the administrative costs of accounts with small balances, such as overdraft fees, which make up 75\% of all bank fees (Maremont \& McGinty, 2014). Those consumers who are the least able to afford the fees pay the most to use checking accounts. Ninety percent of the fees are paid by $10 \%$ of the customers (Crepeau, 2014). Banks earn approximately $\$ 17$ billion annually from overdraft and insufficient funds fees (CFPB, 2017).

\section{Lack of Optimizing Incentives}

A second policy root lies in bank regulations that do not fully optimize incentives to offer basic accounts. Offering a basic, affordable bank account holds the potential to be rewarded within the requirements of the Community Reinvestment Act (CRA), a bank regulation that requires and incentivizes products and services to low- and moderate-income communities. Under the CRA's Service Test, banks have the potential to be rewarded for offering low-cost bank accounts (FDIC 2016a). However, this incentive is weak, and few banks nationally offer accounts that meet national standards for affordability and accessibility (CFE, 2020). 


\section{Account Physical Access Challenges}

Physical access challenges to banks that consumers face influences their account ownership and usage. As a result of federal policy changes, banks are merging and closing branches in underserved communities at a record pace in recent years (Ensign et al., 2018, February 5), which has drastically reduced the number of branches since 2010 (FDIC, n.d.). Opportunities to access a bank account using face-to-face interaction with bank staff, used more by financially vulnerable populations, is therefore more difficult (FDIC, 2018). At the same time, reliable, affordable internet service lags in underserved communities, making it more difficult to consistently access online accounts (Friedline et al., 2020). Physical access to a bank can also affect available options for low-cost accounts; account features, such as high balance requirements and fee structure, are less attractive among banks physically located in black and Latinx communities (Faber et al., 2018).

\section{Policy Suggestions to Address the Problems of Unbanked and Underbanked}

A broad range of policy ideas have been proposed by researchers, scholars, and government actors. These policy ideas are centered on the type of institution permitted to offer accounts, policy and regulations regarding banks, their regulations and their environment, as well as policies directly relating to bank accounts.

\section{Type of Institution}

Among the most expansive proposals are those that would increase the type of institutions that offer low-cost bank accounts. One example is to allow the US Post Office to offer basic accounts, as it did between 1911 and 1967 (Baradaran, 2014; Servon, 2017). Another idea is to offer basic accounts for consumers directly from the Federal Reserve Bank, bypassing retail banks (Ricks et al., 2020). Expanding the capacity and range of products and services for mission-oriented financial institutions, such as community development financial institutions, could allow them to offer low-cost accounts (Birkenmaier, 2018).

\section{Policy Regarding Banks, Bank Regulations, and Banking Environment}

Other policies would expand access to banking and financial services in underserved communities through additional branches, changing the regulatory emphasis, and strengthening the physical infrastructure through which banking is delivered. Policy that promotes bank branch location in underserved communities could allow for easier account access (Friedline et al., 2019a, b), as would increasing the sheer number of bank branches so that bank branches outnumber more costly non-bank financial institutions offering AFS in underserved communities (Friedline et al., 2019a, b). 
Changing CRA regulation could also have a profound effect on the number of banks offering affordable accounts (FDIC, 2016a). Increasing the weight given to low-cost accounts in the CRA Service Test could incentive low-cost accounts (Friedline et al., 2018). Changing regulations could also add increased consumer pressure on banks to provide affordable account in two ways. First, banks could be required to providing account information in easy-to-locate, standardized formats for straight-forward comparative shopping of their account offering (Birkenmaier et al., 2021). Second, making it easier to change banks could create increased pressure on banks to retain their customers through more attractive account offerings (Bernardo, 2015; du Toit \& Burns, 2016).

Policy could also address the environment that influences consumers related to bank accounts in several ways. First, expanding affordable, reliable internet connectivity would allow consumers to securely access more account options, particularly in lower-income and marginalized communities (Friedline et al., 2020). Online and mobile banking holds the potential to expand banking access, but strong, consistent internet connectivity is needed (FDIC, 2020). Second, supporting and expanding the capacity of the federal Consumer Financial Protection Bureau [CFPB] may affect the supply of affordable accounts (CFPB, 2017; Evans \& Stein, 2017). The CFPB offers consumers key government resources to address banking concerns, such as unfair, deceptive, or abusive practices related to accounts, that decrease consumer costs and increase consumer trust.

\section{Policy Regarding Bank Account Requirements}

Expanding access to a safe and affordable account could also occur through policy change directly related to bank accounts. For example, a new law could regulate bank account features, costs, and fees (CFE, 2020). Requiring all retail banks to offer basic accounts at very low cost by law is another option (Government of Canada, 2017). Likewise, regulations could serve to expand the use of municipal identification cards as acceptable identification to open an account (Center for Popular Democracy, 2013).

\section{Study Research Questions and Rationale}

Our analysis sought to answer the following research questions: (1) What policy goals that may impact the availability of low-cost, basic bank accounts have been introduced in Congress as legislation? (2) How far in the legislative process did the legislation advance? (3) What populations did these proposed laws target? and (4) What are the policy goals pursued most ardently over the past 20 years related to affordable bank accounts? The researchers did not generate hypothesis related to these questions because there was a lack of related research to consult.

These questions are grounded in policy analysis research regarding the promotion of policy goals through legislation. Policy development research suggests that policy actors (such as legislators) can define policy problems and public policy responses in various ways due to different causal attributions and policy interest alignment (Stone, 2012). 
These perspectives and responses impact the degree to which policy goals are pursued in legislation. Policy proposals introduced as legislation can also reflect the author's perception about the weight of the evidence of the problem, complexity of the problem, ideology, and their personal motivations and agendas (McConnell \& Hart, 2019), and the likelihood of successfully passing the proposal. Policy proposals that specify target populations, such as the unbanked, may provide strategic benefits (Stratmann, 2013), yet policy often targets the general populations for reasons of partisan protection, expansion, and policy maintenance (Balla et al., 2002; Holyoke, 2009).

\section{Methods}

This study used the method of policy mapping, which is a systematic content analysis technique wherein researchers identify and analyze policy content in a topical area (Anderson et al., 2008; Esdaile et al., 2019; Hare et al., 2016). Policy mapping can identify policy gaps, and provide information about trends and status of policy in a given area. This evidence can provide information for future policy advocacy and a foundation on which research on policy implementation and enforcement occurs (Burris et al., 2016). Results can also provide evidence for the magnitude and nature of policy attention to a particular issue (Esdaile et al., 2019).

\section{Data Collection and Parameters}

This study focused on bills and resolutions introduced at the US Congressional level, rather than the state level. Federal bills are models for legislation at subordinate (e.g., state and municipal) levels (Purtle \& Lewis, 2017). Banks and credit unions can be chartered at both the federal and state levels, but all banks are regulated by the federal government. Using Congress.gov, a publicly available database that catalogs all bills, amendments, and resolutions introduced in the US House and Senate, the research team searched for federal legislation related to basic bank accounts. Using the search terms "bank account," "checking account," and "transaction account," the researchers searched for any bill or resolution containing these exact phrases between 1999 and 2020 (June) (106th-116th Congress) anywhere in the bill summary. The following options were checked for each of the searches: word variants, all legislation, public and private legislation, any action, and any committee. This initial search yielded $n=144$ unduplicated bills and resolutions. The researchers manually identified and removed legislation that was earlier versions of policies introduced in multiple sessions of Congress (whose time period is included), duplicate polices introduced in both the House and Senate, bills primarily focused on lending, terrorism, FDIC insurance, and bills focused on one person. During the coding process, bills and resolutions that failed to address bank accounts in a substantive way were identified and excluded $(n=80)$. From the remaining 64 unique legislative items, we manually identified and removed legislation that was introduced in more than one Congress without substantive change $(n=18)$, retaining only the most recent version for coding in the final dataset. Similarly, we removed 
items $(n=14)$ that were introduced in identical or near-identical versions in both the House and Senate in the same Congress, keeping only the House version. The final dataset was $n=32$ unique bills representing 64 total bills.

\section{Coding Categories}

The researchers established categories and codebook prior to beginning coding (Purtle \& Lewis, 2017) and followed the example process of Bowen and Irish (2019) in coding. The codebook included basic information as well as four goal categories related to our research questions about the policy goal and focal population in legislation. Basic information included bill number and name, whether the bill had a companion bill (introduced in same Congress in same or different chamber), whether the bill had a matching bill (in a different Congress), number of Congress' introduced (106th-116th), the final stage reached (e.g., committee assignment, passed one chamber, etc.), the sponsor party (Democrat, Republican or Independent), and whether the bill had bipartisan support (indicated by the presence of at least one cosponsor with a different political party affiliation than the sponsor). Any target populations mentioned were also coded.

For policy goals, as seen in Table 1, the researchers began coding based on six major policy goals: (1) expanding access to basic bank accounts, (2) expanding

Table 1 Taxonomy of goals and illustrative mechanisms of consumer bank account-related policy

\begin{tabular}{ll}
\hline Goal & Illustrative mechanisms \\
\hline Expand access to accounts & Increase support for mission-oriented financial services \\
& Recalculate the formula for CRA credits \\
& Expand affordable, reliable Internet connectivity \\
& Locate bank branches in lower-income communities \\
& Increase density of bank branches relative to AFS \\
& Ensure the right to a bank account \\
& Expand use of municipal identification cards for banking \\
& Make it easier for consumers to switch banks \\
& Make it easier to open accounts \\
& Incentivize banks to offer low-cost accounts \\
& Promote technology for access \\
US postal banking & Regulation and consumer protection related to higher \\
New institutions offer accounts & cost for communities of color for basic banking \\
tions and communities & Reduce fees \\
Reduce costs of accounts & Extend FDIC/NCUA account insurance \\
Increase consumer protection & Protect from unfair/deceptive/abusive account practices \\
& Protect the Consumer Financial Protection Bureau \\
& Create standards for affordable basic accounts \\
& Provide consumer-friendly product information \\
\hline &
\end{tabular}


the type of institutions that offer basic accounts, (3) expanding account access in minority populations and communities, (4) reducing the costs of basic accounts, (5) increasing consumer protections, and (6) increasing consumer disclosure. As a starting point for coding, the goals and illustrative mechanisms were created through extensive literature review of research studies, academic scholarship, and "grey" literature. Some mechanisms have received study and research (e.g., postal banking (Office of the Inspector General, United States Postal Service, 2014; affordable account standards (Covington \& Liu, 2019)), while others have only been suggested (e.g., expand affordable and reliable internet connectivity (Friedline \& Chen, 2020)).

The codes were not mutually exclusive, and the coding scheme did not specify a maximum for the number of goal codes that could apply to a single bill or resolution. New illustrative mechanisms were added during the process of coding. Focal population was coded based on any target population named in the proposed legislation. For ardently pursued legislation, the researchers coded for legislation introduced into both chambers in the same Congress ("companion"), identical (or nearly identical) legislation introduced in subsequent Congresses ("matching"), and both.

\section{Coding Process}

The two researchers independently coded the basic information and illustrative mechanisms related to the policy goals. The researchers coded the basic information using the summary provided, and coded policy goals using the full text of the bill using the illustrative mechanisms in Table 1. Only bill sections related to bank accounts were coded. The researchers met to review codes after independently coding about $10-15 \%$ of the bills, and developed new codes as needed. The researchers coded independently then met regularly to compare codes and add new codes as needed. Coding discrepancies were resolved through collaboratively reviewing the legislative text, and discussion among the researchers to reach a consensus decision (Krippendorff, 2018). Many discrepancies involved a coder lack of experience with a particular product or process (e.g., the timing of processing of checks relative to deposits by banks) or misreading or misinterpreting text sections. Inter-coder agreement (Cohen's kappa statistic) was calculated only for illustrative mechanisms of the policy goals because interpretation was unnecessary for the basic information categories. The researchers coded text for provisions that could directly or indirectly support the goal, or illustrative mechanism.

\section{Results}

Table 2 describes basic characteristics of legislation in the dataset $(N=32)$. No resolutions were included in the dataset. The bills were fairly evenly distributed among the various Congresses, with the largest number in the 116th Congress (2019-2021). The vast majority was House bills (90.6\%), and introduced by Democrats $(78.1 \%)$. A minority of bills had companion legislation (34\%) or similar bills introduced over more than one Congressional session ("matched") (38\%). A very small minority 
Table 2 Basic characteristics of bank account-related bills in the US Congress, 1999-2020 (106-116th Congress) $(N=32)$

\begin{tabular}{ll}
\hline Coding category & $N(\%)$ \\
\hline Congress (years) & \\
106th (1999-2001) & $2(6.3)$ \\
107th (2001-2003) & $1(3.1)$ \\
108th (2003-2005) & $2(6.3)$ \\
109th (2005-2007) & $4(12.5)$ \\
110th (2007-2009) & $1(3.1)$ \\
111th (2009-2011) & $4(12.5)$ \\
112th (2011-2013) & $2(6.3)$ \\
113th (2013-2015) & $3(9.4)$ \\
114th (2015-2017) & $3(9.4)$ \\
115th (2017-2019) & $4(12.5)$ \\
116th (2019-2021) & $6(18.8)$ \\
Chamber of origin & \\
House & $29(90.6)$ \\
Senate & $3(9.4)$ \\
Sponsor party & \\
Democrat & $25(78.1)$ \\
Republican & $7(21.9)$ \\
Bipartisan support & $4(12.5)$ \\
Ardently pursued & \\
Companion bill introduced & $11(34)$ \\
Matching bill introduced & $12(38)$ \\
Both co-introduced and matched & $5(15.6)$ \\
Final status & \\
Introduced/assigned to committee & $24(75)$ \\
Committee hearing & $1(3.1)$ \\
Passed one chamber & $4(12.5)$ \\
Tassed both chambers and became law & $3(9.4)$ \\
Unbanked & \\
At risk youth & 2 \\
Unbanked and underbanked & 1 \\
Multiple vulnerable populations & 2 \\
\hline &
\end{tabular}

had both companion legislation and matched legislation (15.6\%). Most items (75\%) did not progress beyond introduction and assignment to committee. A minority of bills $(25 \%)$ targeted a specific population, such as the unbanked or underbanked. A few bills were well-known bills (e.g., H.R. 4173, 111th Congress, Dodd-Frank Wall Street Reform and Consumer Protection Act), while most were obscure.

Table 3 summarizes coding of goals, illustrative mechanisms, ardently pursued legislation, target populations, and illustrative examples of legislation. Cohen's 


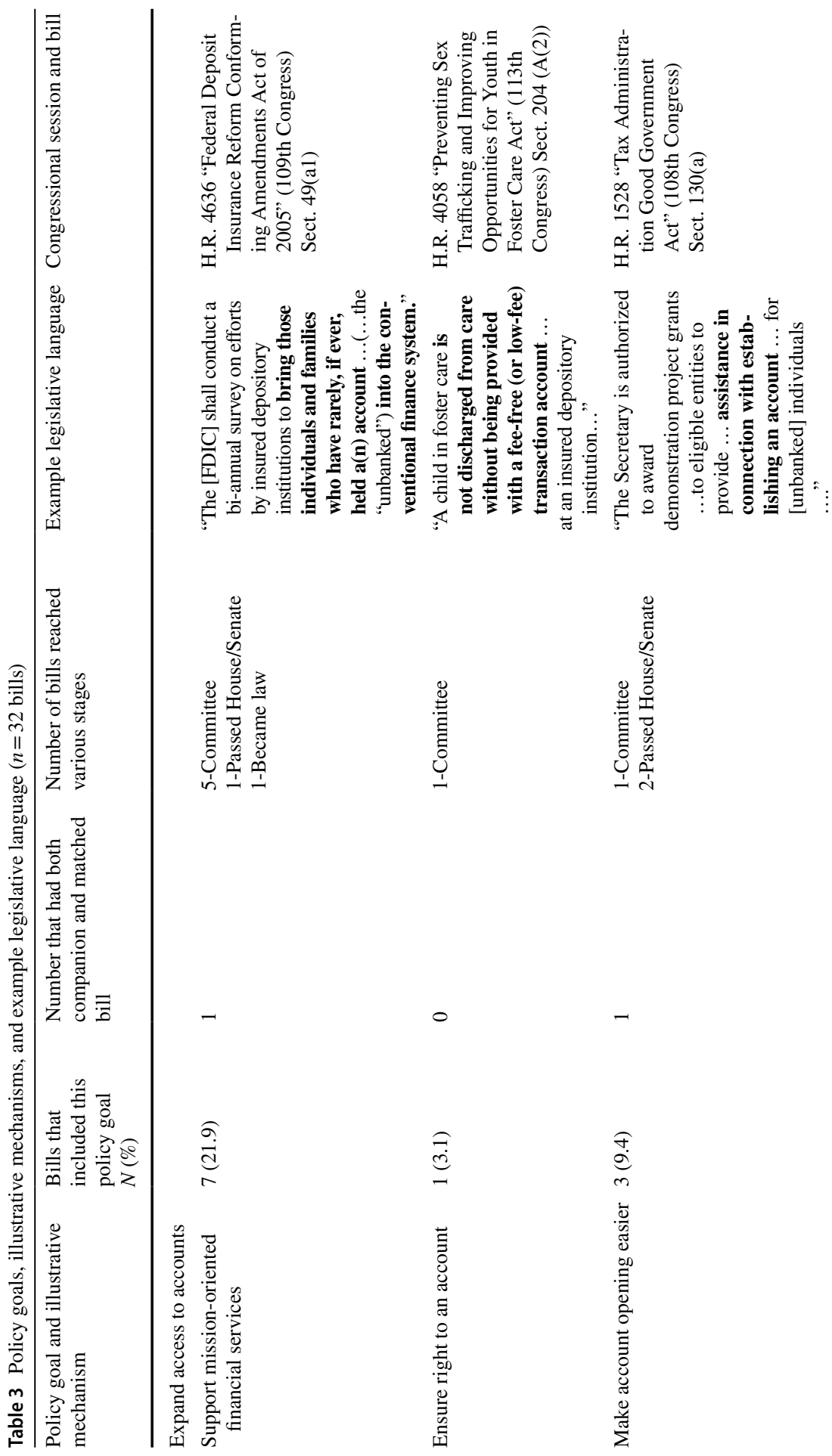










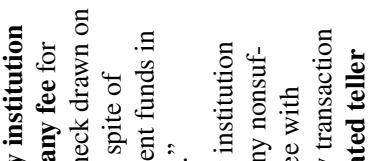

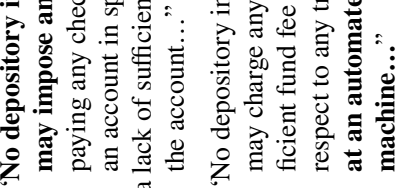

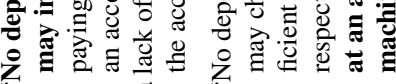

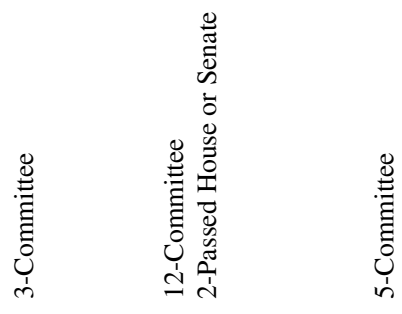

$\widehat{e}$








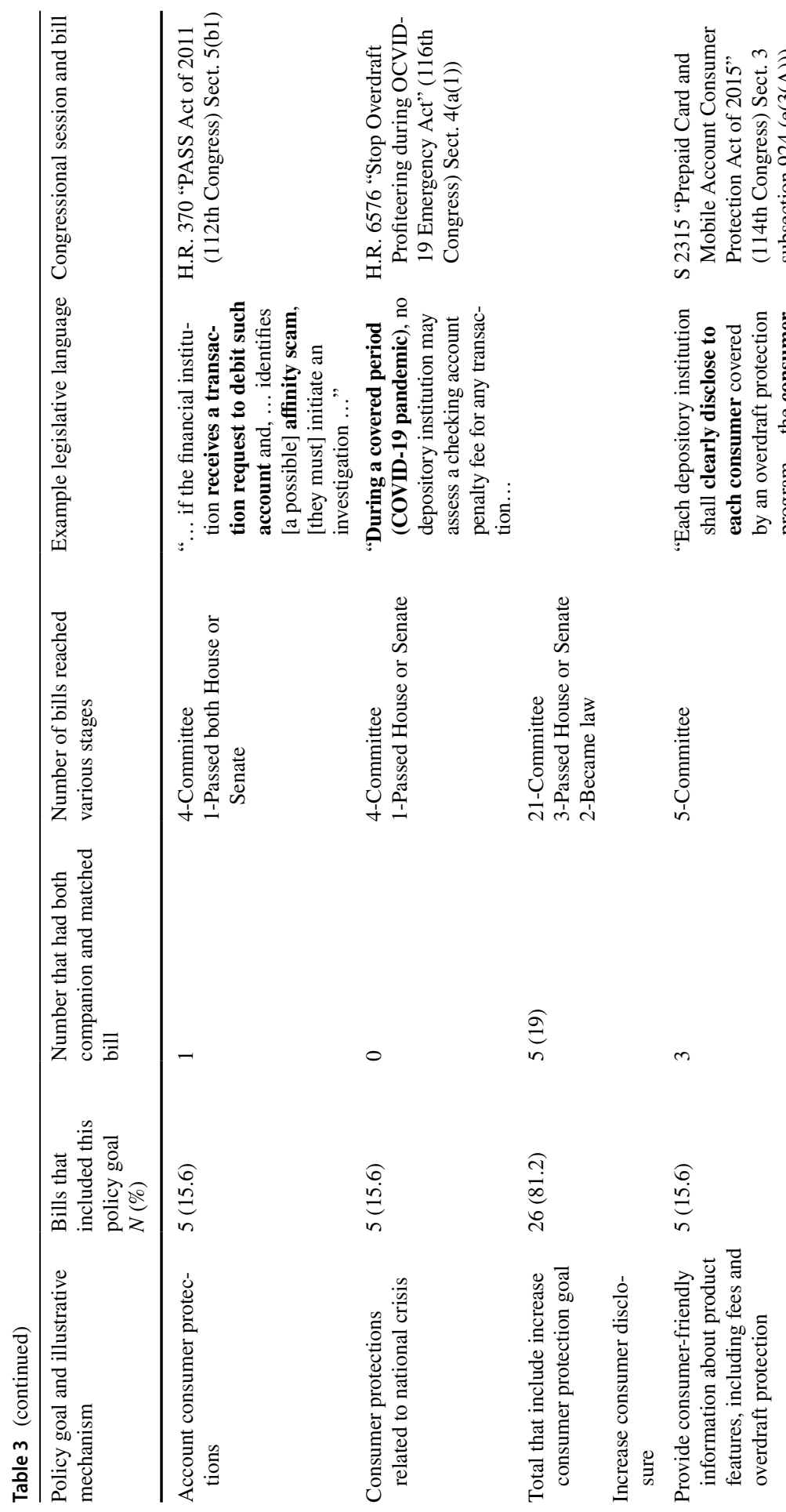




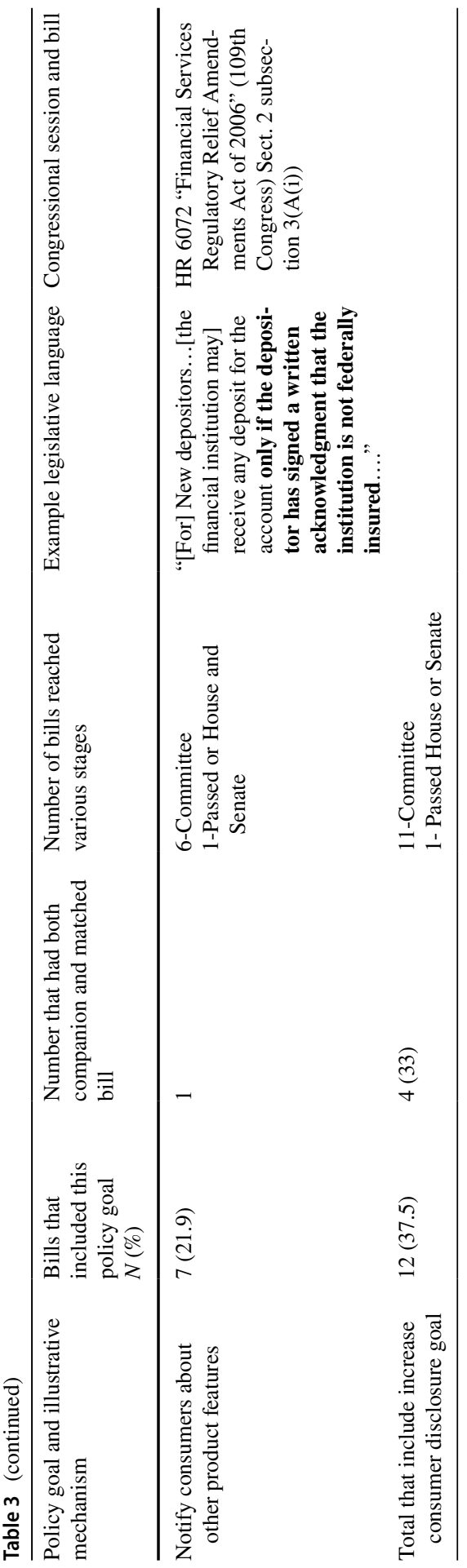


kappa statistic for illustrative mechanisms (0.79) indicates substantial inter-coder agreement.

The policy goal of expanding account access in minority populations and communities was not represented in the dataset. Several illustrative mechanisms were also not represented. Related to the goal of expanding access to bank accounts, items related to the Community Reinvestment Act (CRA), internet access, bank branch location and density, identification cards, and switching banks were not represented in the dataset. Related to the goal of consumer protection, items related to protecting and strengthening the CFPB were not represented. Related to consumer disclosure, creating or supporting standards for affordable basic accounts was also not in the dataset.

Three goals were approximately equally addressed in the legislation: expanding access to bank accounts (81.2\% of legislation), increasing consumer protection (81.2\%), and reducing costs of basic accounts (78.2\%). Increasing consumer disclosure $(37.5 \%)$ and expanding the type of institutions that offer basic accounts $(9.4 \%)$ were addressed infrequently in the legislation. The policy goals that have progressed the furthest in federal legislation are expanding access and increasing consumer protection; $8 \%$ of bills coded with both policy goals became law. For example, for the goal of expanding access, H.R. 4636, the Federal Deposit Insurance Reform Conforming Amendments Act of 2005 (109th Congress) required FDIC to conduct a bi-annual national study of the unbanked and underbanked. For the policy goal of increasing consumer protection, H.R. 1095 disallows penalties for withdrawing or transferring funds from an account. The goal that achieved the least progress is to expand type of institutions that offer basic accounts. For example, H.R. 3171, the Bridging Bank to Recovery Act of 2009 (111th Congress) proposed to create a new "bridging bank" that would provide basic accounts and access to credit for the unbanked, underbanked, and consumers with low credit scores. This bill only went through the initial steps, and never had a committee hearing.

Within the policy goals, support for mission-oriented financial services $(21.9 \%)$ was the most common illustrative mechanism for the expanding access goal. For the goal of reducing the costs of accounts, legislation that related to all types of fees was most common (43.8\%). Protecting consumers from unfair/deceptive/abusive bank account practices and products and services was the most common mechanism for the goal of increasing consumer protection (28.1\%). The illustrative mechanism most common for the goal of increasing consumer disclosure was notifying consumers about other (non-fee) product features (21.9\%). The policy that had illustrative mechanisms that achieved the most progress, without becoming law, were expanding access and reducing costs. Within expanding access, two bills related to making it easier to open accounts passed one chamber: H.R. 4058, 113th Congress, the Preventing Sex Trafficking and Improving Opportunities for Youth in Foster Care Act, which passed the House, would require staff to open accounts for youth prior to discharge from the foster care system, and H.R. 1528, 108th Congress, the Tax Administration and Good Government Act, which passed the Senate, would make it easier to open accounts when filing taxes through government-supported tax filing sites for low- and moderate-income consumers. Regarding reducing costs, two bills related to reducing fees on accounts also passed the House: H.R. 4058, 113th Congress, the 
Preventing Sex Trafficking and Improving Opportunities for Youth in Foster Care Act (discussed earlier), and HR 1375, 108th Congress, the Financial Services Regulatory Relief Act of 2004, which required a survey of bank fees. The policy goal pursued most ardently through the combination of companion and matching bills is increasing consumer disclosure, with $33 \%$ of legislation that includes an illustrative mechanism for this goal being pursued with the combination of companion and matching bills. Reducing cost was also ardently pursued through $28 \%$ of legislation that includes an illustrative mechanism for this goal featuring both companion and matching bills. Bills related to expanding access (19\%) and type of institutions (0\%) were pursued the least ardently.

\section{Discussion}

This study reports on the first comprehensive analysis of the basic characteristics, goals, illustrative mechanisms, and progress in the US Congress on the goals of reducing the number of unbanked and underbanked Americans between 1999 and 2020. The 32 bills in the dataset indicate some legislative attention across the time period to the policy goals and illustrative mechanisms when the topic was emerging as an area of concern at the federal level. The Congressional response particularly occurred in the most recent Congress (116th, 2019-2021), and with bipartisan attention, although heavily skewed toward those in the Democratic party. Most of the bills were small scale bills, the majority of which did not advance past committee assignment.

Although most of the policy goals in our taxonomy were reflected in the dataset and new illustrative mechanisms were located, Congressional attention to this topic is noticeably lax in comparison to the attention paid by federal regulatory agencies and related academic literature. This finding of less attention to banking consumer interests is consistent with prior research that Congressional attention to consumer interests has dropped in recent decades relative to business interests (Bykerk \& Maney, 2010). The progress of the bills in the dataset has been mostly minimal. Only three bills representing two policy goals have become law (expand access to bank accounts and increase consumer protection). This finding is not surprising, given that on average, only two-six percent of introduced bills passed into law in Congress during the study period (Civic Impulse, 2021).

The most commonly occurring policy goals of expanding access, reducing costs, and increasing consumer protection are primarily focused on proximal factors for lack of access, rather than the root causes of access barriers. For example, the policy goal of expanding the type of institutions that offer basic accounts, such as a new type of bank, have very few bills introduced about them and they failed to progress past the first steps. The illustrative mechanism that was the most expansive in terms of rights (e.g., ensuring the right to a bank account) stalled at committee assignment, despite the fact that it would be a prevention measure. These findings are consistent with the concept that incremental, rather than structural, change is often pursued by legislators (Baumgartner et al., 2018). Increasing consumer disclosure and reducing 
account cost was pursued most ardently of all of the policy goals, while expanding access and type of institutions were pursued the least.

The bills included little language about focal populations. Only six bills mentioned any populations at all. This lack of mention is consistent with the idea of legislation benefitting the general population as a strategy that increases the chances of passage (Balla et al., 2002; Holyoke, 2009; Strolovitch, 2006). Legislation that benefits the general population, including advantaged subgroups, can also positively impact financially vulnerable populations, even when not specifically mentioned in the legislation (Strolovitch, 2006). For example, expanding the institutions that can offer basic accounts to the US Postal Service can benefit the general population and offer convenience to all, including the unbanked and underbanked populations. Thus, the fact that so few bills included any mention of financially vulnerable populations may in fact help the progress of the bills because of a wider beneficiary population.

Not all goals and illustrative mechanisms in our taxonomy were reflected in the dataset. The policy goal of expanding account access in minority populations and communities was not represented in the dataset. Thus, no introduced legislation has sought to specifically target minority populations and communities that are disproportionally represented among the unbanked and underbanked (FDIC, 2020). The missing illustrative mechanisms related to the goal of expanding access to bank accounts are notable because all have received attention in the research literature as critical to reducing the number of unbanked and underbanked (Center for Popular Democracy, 2013; Friedline et al., 2020), in particular, bank branch location and density of banks relative to Alternative Financial Services (Friedline et al., 2019a, b). Regarding consumer protection and disclosure, there were no items related to protecting and strengthening the CFPB, which provides important consumer advocacy for individual consumers related to the banking industry. Also missing was the creation of standards for affordable basic accounts, which is a growing movement across the country (Erwitt et al., 2019; Wack, 2020).

To address the challenges of the unbanked and underbanked through federal legislation, advocates could focus on the policy goals and illustrative mechanisms that have achieved legislative movement in the past by passing either the House or the Senate, yet have not become law. For example, under the policy goal of expanding access to bank accounts, the illustrative mechanism of making it easier to open accounts had two bills that passed one chamber (H.R. 4058, 113th Congress and H.R. 1528, 108th Congress). Under the goal of reducing costs, the illustrative mechanism of generally reducing fees (not specifically related to ATM or overdraft fees) has also achieved momentum in the past through H.R. 4058, 113th Congress and H.R. 1375, the 108th Congress. Advocates may also want to focus on legislation that directly affects the account fee structure, given its prominence in reasons given for unbanked status (CFPB, 2017; FDIC, 2020). Consumer protections related to accounts and those related to a national crisis have also passed one chamber. Legislation that would increase consumer notification about account features, that furthers the policy goal of increasing consumer disclosure, has achieved passage within one chamber. These results suggest that legislation that is related to fees in general, rather than fees tied to specific activities, may gain more policy movement. 
Legislation related to consumer protections may be another likely avenue, given these results of substantial legislative movement of related bills.

\section{Limitations}

These findings should be considered in light of the study's limitations. First, this study omits policy making that occurs in other contexts, such as the federal regulatory process (FDIC, 2016a), the courts, and state legislation. Second, only bills that specifically mentioned bank accounts were included. Relevant legislation may have been missed that had an indirect effect on bank accounts, that did not mention accounts, or that benefitted financially vulnerable populations and communities. Third, the nature of legislative attention to various goals and illustrative mechanisms related to bank account access deserves a closer examination in future research. For example, future studies could analyze the influence of companion and matching bills related to the final status of legislation, as well as the nature of legislation within which language about account access was situated for some included bills. Lastly, future research should include more contextual factors, including dominant political party within the chambers and in the executive branch.

\section{Conclusion}

The presence of the unbanked and underbanked populations through the study period suggests that additional policy development and legislative attention is needed to meet the needs of these populations. Moving forward, policy advocates may wish to focus on impactful areas that shows evidence of movement forward in the legislative process, such as making it easier to open accounts, reducing fees, and increasing consumer protections. Policy advocates may also wish to focus their attention on areas that are under-addressed in the past legislative response (e.g., expanding the type of institutions that offer basic accounts, and the basic right to an account). In sum, the findings of this study indicate that despite some congressional legislative activity in the past decade, the sufficiency and effectiveness of proposed policy solutions remain insufficient to address the problems.

Acknowledgements The authors would like to thanks Kate Miller, BSSW student at Saint Louis University, for her invaluable contribution to this article.

Author Contribution Dr. Julie Birkenmaier created the project, collected the data, coded and analyzed the data, and wrote the entire paper. Alana Jansson managed the data and screened and coded the data.

Availability of Data and Material The data is already public.

\section{Declarations}

Conflict of Interest The authors declare no competing interests. 


\section{References}

American Banker. (2014). Post office banking around the globe. https://www.americanbanker.com/ slideshow/post-office-banking-around-the-globe

American Bankers Association [ABA]. (2021). Join the bank on movement. https://www.aba.com/ banking-topics/consumer-banking/inclusive-banking/bank-on

Anderson, S., Allen, P., Peckham, S., \& Goodwin, N. (2008). Asking the right questions: Scoping studies in the commissioning of research on the organisation and delivery of health services. Health Research Policy and Systems, 6(1), 1-12. https://doi.org/10.1186/1478-4505-6-7

Balla, S. J., Lawrence, E. G., Maltzman, F., \& Sigelmann, L. (2002). Partisanship, blame avoidance, and the distribution of legislative pork. American Journal of Political Science, 46(3), 515-525. https://doi.org/10.2307/3088396

Baradaran, M. (2014). It's time for postal banking. Harvard Law Review Forum, 127, 165-175.

Baradaran, M. (2020). Banking on democracy. Washington University Law Review, 98(2), 353-418. https://openscholarship.wustl.edu/law_lawreview/vol98/iss2/5

Baumgartner, F. R., Jones, B. D., \& Mortensen, P. B. (2018). Punctuated equilibrium theory: explaining stability and change in public policymaking. In C. M. Weible, \& P. A. Sabatier (Eds.), Theories of the Policy Process (pp. 55-102). Routledge.

Bernardo, R. (2015, Jul 24). Close your account \& switch banks: the breakup guide. Wallethub. https://wallethub.com/edu/sa/how-to-close-a-bank-account/14327

Birkenmaier, J. M. (2018). Promoting financial credit-building for financially vulnerable families. Families in Society, 99(2), 93-99. https://doi.org/10.1177/1044389418767825

Birkenmaier, J. M., Huang, J., \& Janssen, A. (2021). Bank compliance with national transaction account standards: evidence from a mid-western metropolitan area. Unpublished manuscript submitted for publication.

Board of Governors of the Federal Reserve. (2019). Report on the economic well-being of U.S. households in 2019 - May 2020. https://www.federalreserve.gov/publications/2020-economic-wellbeing-of-us-households-in-2019-banking-and-credit.htm\#

Bowen, E., \& Irish, A. (2019). A policy mapping analysis of goals, target populations, and punitive notions in the U.S. congressional response to the opioid epidemic. International Journal of Drug Policy, 74, 90-97. https://doi.org/10.1016/j.drugpo.2019.09.014

Burris, S., Hitchcock, L., Ibrahim, J., Penn, M., \& Ramanathan, T. (2016). Policy surveillance: A vital public health practice comes of age. Journal of Health Politics, Policy and Law, 41(6), 1151-1173. https://doi.org/10.1215/03616878-3665931

Bykerk, L., \& Maney, A. (2010-2011). Consumer protection policy issues on the Congressional agenda. Political Science Quarterly, 125(4), 639-655. https://www.jstor.org/stable/25767093

Center for Popular Democracy. (2013). Who we are: municipal ID cards as a local strategy to promote belonging and shared community identity. https://populardemocracy.org/sites/default/files/ publications/CPD_Municipal_ID_layout_final.pdf

Cities for Financial Empowerment Fund [CFE]. (2020). Banks and credit unions across the country are joining the Bank On movement. https://joinbankon.org/accounts/

Civic Impulse, LLC. (2021). Statistics and historical comparison. Govtrack. https://www.govtrack.us/ congress/bills/statistics

Consumer Financial Protection Bureau [CFPB]. (2017). A closer look: overdraft and the impact of opting-in. https://files.consumerfinance.gov/f/documents/201701_cfpb_Overdraft-and-Impactof-Opting-In.pdf

Covington, M., \& Liu, M. (2019). The Bank On national data hub: findings from the first year. Federal Reserve Bank of St. Louis. https://www.stlouisfed.org/ /media/Files/PDFs/Community-Devel opment/Bank-On/2019_BankOn_report_final.pdf?la=en

Crepeau, M. (2014, Sept 8). Less money, pricier banking. Chicago Tribune, p. 10. http://www.newyorker. com/business/currency/the-high-cost-for-the-poor-of-using-a-bank

du Toit, G., \& Burns, M. (2016). Customer loyalty in retail banking: Global edition 2016. Bain \& Company. https://www.bain.com/insights/customer-loyalty-in-retail-banking-2016

Ensign, R. L., Raexrode, C., \& Jones, C. (2018, February 5). Banks shutter 1,700 branches in fastest decline on record. The Wall Street Journal. https://www.wsj.com/articles/banks-double-downon-branch-cutbacks-1517826601 
Erwitt, A., Plat, K., Bradley, K., \& Diner, P. (2019). The present and. future of Bank On account data: pilot results and prospective data collection. St. Louis Federal Reserve Bank and Cities for Financial Empowerment. https://www.stlouisfed.org/ /media/Files/PDFs/Community-Development/ Bank-On/bankon_data.pdf?la=en

Esdaile, E., Thow, A. M., Gill, T., Sacks, G., Golley, R., Love, P., Wen, L. M., \& Rissel, C. (2019). National policies to prevent obesity in early childhood: Using policy mapping to compare policy lessons for Australia with six developed countries. Obesity Reviews, 20(11), 1542-1556. https://doi. org/10.1111/obr.12925

Evans, G., \& Stein, G. (2017). Know before you owe: we are designing new overdraft disclosure forms. Consumer Financial Protection Bureau. https://www.consumerfinance.gov/about-us/blog/know-youowe-we-are-designing-new-overdraft-disclosure-forms/?utm_content=buffer4a01d\&utm_medium= social\&utm_source=twitter.com\&utm_campaign=buffer

Faber, J., Friedline, T., \& Policy, F. C. S. (2018). The racialized costs of banking. New America. https:// community-wealth.org/sites/clone.community-wealth.org/files/downloads/The_Racialized_Costs_ of_Banking_2018-06-20_205129.pdf

Federal Deposit Insurance Corporation [FDIC]. (n.d.). BankFind Suite: final annual historical bank data. https://banks.data.fdic.gov/explore/historical/?displayFields=STNAME\%2CNew_Char\% 2CBRANCHES \&selectedEndDate $=2018 \&$ selectedReport $=$ CBS \& selected StartDate $=1934 \&$ selectedStates $=0 \&$ sortField $=$ YEAR \&sortOrder $=$ desc

Federal Deposit Insurance Corporation [FDIC]. (2009). FDIC national survey of unbanked and underbanked households. https://www.fdic.gov/analysis/household-survey/index.html

Federal Deposit Insurance Corporation [FDIC]. (2012a). 2011 FDIC national unbanked and underbanked households. https://www.fdic.gov/analysis/household-survey/index.html

Federal Deposit Insurance Corporation [FDIC]. (2012b). 2011 FDIC survey of banks' efforts to serve the unbanked and underbanked. http://www.fdic.gov/unbankedsurveys/2011survey/2011report.pdf

Federal Deposit Insurance Corporation [FDIC]. (2014). 2013 FDIC national unbanked and underbanked households. https://www.fdic.gov/analysis/household-survey/index.html

Federal Deposit Insurance Corporation [FDIC]. (2016a). FDIC consumer compliance examination manual. https://www.fdic.gov/regulations/compliance/manual/11/XI-12.1.pdf

Federal Deposit Insurance Corporation [FDIC]. (2016b). 2015 FDIC national unbanked and underbanked households. https://www.fdic.gov/analysis/household-survey/index.html

Federal Deposit Insurance Corporation [FDIC]. (2018). 2017 FDIC national unbanked and underbanked households. https://www.fdic.gov/analysis/household-survey/index.html

Federal Deposit Insurance Corporation [FDIC]. (2020). How America banks: household use of banking and financial services, 2019 FDIC Survey. https://www.fdic.gov/analysis/household-survey/index. html

Federal Deposit Insurance Corporation [FDIC]. (2021). \#GetBanked. https://www.fdic.gov/getbanked/ index.html

Friedline, T., \& Chen, Z. (2020). Digital redlining and the rintech marketplace: Evidence from US zip codes. Journal of Consumer Affairs. https://doi.org/10.1111/joca.12297

Friedline, T., Despard, M., \& Birkenmaier, J. M. (2018). Policy recommendations for expanding access to banking and financial services. Grand Challenges for Social Work initiative Policy Brief No. 11-4. Cleveland, $\mathrm{OH}$ : American Academy of Social Work and Social Welfare. https://openscholarship. wustl.edu/cgi/viewcontent.cgi?article=1780\&context=csd_researc

Friedline, T., Despard, M. R., \& West, S. (2019a). Does the composition of financial services in a community relate to an individual's savings account ownership? Journal of Community Practice, 27(1), 5-30. https://doi.org/10.1080/10705422.2019.1580652

Friedline, T., Dunham, I. M., \& O'Brien, M. (2019b). The financial services environment and schools' savings rates in the San Francisco Kindergarten to College program. Journal of Consumer Affairs, 53(4), 1797-1824. https://doi.org/10.1111/joca.12264

Friedline, T., Naraharisetti, S., \& Weaver, A. (2020). Digital redlining: Poor rural communities' access to fintech and implications for financial inclusion. Journal of Poverty, 24(2), 168-192. https://doi.org/ 10.1080/10875549.2019.1695162

Geffner, M. (2010, July 26). Bank account costs \$250. Bankrate. http://www.bankrate.com/financing/ banking/bank-account-costs-250/

Government of Canada. (2017). CG-2 access to basic banking services regulations: refusal to open an account. https://www.canada.ca/en/financial-consumer-agency/services/industry/commissioner-guidance/guidance2.html 
Hare, K. A., Dubé, A., Marshall, Z., Gahagan, J., Harris, G. E., Tucker, M., Dykeman, M., \& MacDonald, J. A. (2016). Troubling the boundaries: Overcoming methodological challenges in a multi-sectoral and multi-jurisdictional HIV/HCV policy scoping review. Evidence \& Policy: A Journal of Research, Debate and Practice, 12(2), 217-233. https://doi.org/10.1332/174426415X14365286808816

Holyoke, T. T. (2009). Interest group competition and coalition formation. American Journal ofPolicy Science, 53(2), 360-375. https://doi.org/10.1111/j.1540-5907.2009.00375.x

Krippendorff, K. (2018). Content analysis: an introduction to its methodology. Sage Publications.

McConnell, A., \& Hart, P. (2019). Inaction and public policy: understanding why policymakers 'do nothing'. Policy Sciences, 52, 645-661. https://link.springer.com/article/10.1007/s11077-019-09362-2

Maremont, M., \& McGinty, T. (2014, May 11). Why banks at Wal-Mart are among America's top fee collectors. Wall Street Journal. http://online.wsj.com/news/articles/SB10001424052702304734304579515730198367 754?KEYWORDS=maremont\&mg=reno64-wsj

Office of the Inspector General, United States Postal Service. (2014). Providing non-bank financial services for the underserved. https://www.uspsoig.gov/document/providing-non-bank-financial-services-underserved

Purtle, J., \& Lewis, M. (2017). Mapping "trauma-informed” legislative proposals in U.S. Congress. Administration and Policy in Mental Health and Mental Health Services Research, 44, 867-876. https://doi.org/10.1007/s10488-017-0799-9

Ricks, M., Crawford, J., \& Menand, L. (2020). FedAccounts: digital dollars. Vanderbilt Law Research Paper, 18-33.

Servon, L. (2017). The unbanking of America: how the new middle class survives. Houghton Mifflin Harcourt.

Servon, L. J., \& Castro-Cosío, A. (2015). Reframing the debate about financial inclusion: evidence from a up close view of alternative financial services. Federal Reserve Economic Mobility Conference. https://www. stlouisfed.org/ /media/files/pdfs/community\%20development/econ\%20mobility/sessions/servonpaper508. pdf

Stratmann, T. (2013). The effects of earmarks on the likelihood of reelection. European Journal of Political Economy, 32, 341-355. https://doi.org/10.1016/j.ejpoleco.2013.08.001

Stone, D. (2012). Policy paradox: The art of political decision making. Norton.

Strolovitch, D. Z. (2006). Do interest groups represent the disadvantaged? Advocacy at the intersections of race, class, and gender. The Journal of Politics, 68(4), 894-910. https://doi.org/10.1111/j.14682508.2006.00478.x

Wack, K. (2020, Oct 10). New pressure on banks to offer affordable consumer accounts. American Banker. https://www.americanbanker.com/news/new-pressure-on-banks-to-offer-affordable-consumer-accounts

Publisher's Note Springer Nature remains neutral with regard to jurisdictional claims in published maps and institutional affiliations. 